\title{
Coffee by-products as the source of antioxidants: a systematic
}

\section{review [version 1; peer review: 2 approved]}

\author{
Wahyu Lestari1-3, Kartini Hasballah (1D)4, M. Yulianto Listiawan5, Sofia Sofia (D)6,7 \\ ${ }^{1}$ Postgraduate Program, School of Medicine, Universitas Syiah Kuala, Banda Aceh, 23111, Indonesia \\ 2Department of Dermatology, School of Medicine, Universitas Syiah Kuala, Banda Aceh, 23111, Indonesia \\ ${ }^{3}$ Department of Dermatology, Dr. Zainoel Abidin General Hospital, Banda Aceh, 24415, Indonesia \\ ${ }^{4}$ Department of Pharmacology, School of Medicine, Universitas Syiah Kuala, Banda Aceh, 23111, Indonesia \\ ${ }^{5}$ Department of Dermatology, Faculty of Medicine, Universitas Airlangga/Dr. Soetomo General Hospital, Surabaya, 60131, Indonesia \\ ${ }^{6}$ Department of Biochemistry, School of Medicine, Universitas Syiah Kuala, Banda Aceh, 23111, Indonesia \\ ${ }^{7}$ Master of Public Health, School of Medicine, Universitas Syiah Kuala, Banda Aceh, 23111, Indonesia
}

\begin{tabular}{l}
\hline V1 First published: 23 Feb 2022, 11:220 \\
https://doi.org/10.12688/f1000research.107811.1 \\
Latest published: 23 Feb 2022, 11:220 \\
https://doi.org/10.12688/f1000research.107811.1 \\
\hline
\end{tabular}

\section{Abstract}

Background: Solid waste from coffee depulping process threatens the organism in environment as it produces organic pollutants. Evidence suggested that coffee by-product could valorize owing to its potential as antioxidant sources. The aim of this systematic review was to evaluate antioxidant activity of coffee by-products obtained from different coffee variants (arabica and robusta) and processing methods.

Methods: The systematic review was conducted as of May 29, 2021 for records published within the last ten years (2011-2021) using seven databases: Embase, Medline, BMJ, Web of Science, Science Direct, Cochrane, and PubMed. Data on type of specimen, processing methods, and antioxidant activities were collected based on PRISMA guidelines.

Results: Our data suggested that aqueous extract was found to be the most common processing method used to obtain the antioxidant from various coffee by-products, followed by methanol and ethanol extract. A variety of antioxidant properties ranging from strong to low activity was found depending on the variety, type of coffee byproducts (cascara, pulp, husk, silverskin, and parchment), and processing technique. Fermentation employing proper bacteria was found effective in improving the yield of bioactive compounds resulting in higher antioxidant capacity. Applications in feedstuffs, foods, beverages, and topical formulation are among the potential utilization of coffee by-products.

Conclusion: Coffee by-products contain bioactive compounds possessing antioxidant properties which could be used as additives in foods, beverages, and cosmetics. In particular, their benefits in skin care products require further investigation.

\section{Open Peer Review}

Approval Status Ans 12 version 1 23 Feb 2022

$\checkmark$
2

1. Emil Salim ID, Universitas Sumatera Utara, North Sumatera, Indonesia

2. Ghodratollah Panahi ID, Tehran University of Medical Sciences, Tehran, Iran

Any reports and responses or comments on the article can be found at the end of the article. 
Keywords

robusta, arabica, husk, pulp, silverskin, cascara

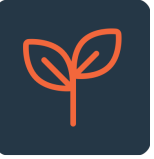

This article is included in the Agriculture, Food

and Nutrition gateway.

\section{Corresponding author: Kartini Hasballah (kartini.hasballah@unsyiah.ac.id)}

Author roles: Lestari W: Conceptualization, Data Curation, Investigation, Methodology, Project Administration, Software, Validation, Visualization, Writing - Original Draft Preparation, Writing - Review \& Editing; Hasballah K: Conceptualization, Resources, Supervision, Validation, Writing - Original Draft Preparation, Writing - Review \& Editing; Listiawan MY: Conceptualization, Resources, Supervision, Validation, Writing - Review \& Editing; Sofia S: Conceptualization, Methodology, Resources, Supervision, Visualization, Writing - Original Draft Preparation, Writing - Review \& Editing

Competing interests: No competing interests were disclosed.

Grant information: The author(s) declared that no grants were involved in supporting this work.

Copyright: (c) 2022 Lestari W et al. This is an open access article distributed under the terms of the Creative Commons Attribution License, which permits unrestricted use, distribution, and reproduction in any medium, provided the original work is properly cited.

How to cite this article: Lestari W, Hasballah K, Listiawan MY and Sofia S. Coffee by-products as the source of antioxidants: a systematic review [version 1; peer review: 2 approved] F1000Research 2022, 11:220 https://doi.org/10.12688/f1000research.107811.1

First published: 23 Feb 2022, 11:220 https://doi.org/10.12688/f1000research.107811.1 


\section{Introduction}

As the world widely popular beverage, ${ }^{1,2}$ coffee has been produced in a large scale causing the emergence of massive organic solid waste. ${ }^{3,4}$ Most of the solid waste is originated from the depulping process, where the coffee bean is separated from the other parts of the coffee cherry. ${ }^{5,6}$ Solid waste from cherry pulp was not well-managed leading to the threat of environmental pollution. ${ }^{7}$ Nevertheless, the solid waste can be utilized for multiple purposes such as bioethanol, ${ }^{8}$ biogas, ${ }^{9}$ compost, ${ }^{10}$ and feedstuffs. ${ }^{11,12}$ Coffee by-products consist of cascara, coffee pulp, coffee husk, coffee silverskin, and coffee parchment. Among them, coffee pulp occupies the most part of coffee by-products containing carbohydrate (50\%), protein $(10 \%)$, fiber $(20 \%)$, fat $(2.5 \%)$, caffeine $(1.3 \%)$, and phenolic compounds. ${ }^{13}$ The phenolic acids in cherry pulp can be detailed as followed; hydro-benzoic acid, chlorogenic acid, ferulic acid, caffeic acid, syringic acid, gallic acid, vanillic acid, and cumaric acid. ${ }^{12,14}$ Many studies have been conducted in coffee. ${ }^{15-20}$

In dry processing, the solid waste majorly produced is husk. ${ }^{6}$ Coffee husk is rich in carbohydrate (8-85\%), followed by protein $(8-11 \%)$, fat $(0.5-3 \%)$, and minerals $(3-7 \%) .{ }^{21}$ Cascara obtained from husk or pulp contains natural antioxidants namely polyphenols, anthocyanin, and vitamin $\mathrm{C}$ along with other bioactive compounds of caffeine, alkaloids, and tannins. ${ }^{22}$ Husk is potential for human consumption due to its nature of free gluten which does not cause allergic reaction. ${ }^{21}$

Taken together, coffee by-products hold a significant potential to be utilized as additives in food products. ${ }^{23,25}$ In fact, foods and beverages derived from coffee by-product have been introduced and recorded in scientific report a long time ago. ${ }^{12}$ In dermatology, the antioxidant properties from coffee by-products could provide skin protection against UV lightinduced damages. ${ }^{26,27}$ Moreover, the content of polyphenols could be used for patient with alopecia, acne vulgaris, fungal infection, hyperpigmentation, or skin aging. ${ }^{28}$ Valorization of coffee by-products in a wide array of fields could offer a solution to the emerging environmental threat due to the overwhelming production of coffee solid waste. ${ }^{24,29}$

So far, the review of coffee by-products only presents the end products in general. ${ }^{10,24,30}$ Most of the reviews discussed about the application of coffee by-products in food and beverage products. ${ }^{12,31}$ Review of coffee-by products with specific topics such as topical formulation ${ }^{32}$ and polymer technology ${ }^{5}$ have been reported. Herein, we discuss the advances of coffee by-products antioxidant activities which were obtained from different coffee variants (arabica and robusta) and processing methods. To the best of our knowledge, the systematic review of antioxidant activities yielded by coffee by-products has never been published.

\section{Methods}

Study setting and eligibility criteria of studies

This systematic review was conducted in accordance to the Preferred Reporting Items for Systematic Reviews and Metaanalyses (PRISMA) guidelines ${ }^{33}$ as previously used elsewhere. ${ }^{34,35}$ Articles were included in this review, when the following criteria were fulfilled: 1). The sample was at least coffee husk, coffee silverskin, coffee pulp, coffee parchment, or the cascara (pulp and outer skin);2). Investigated in-vitro or in-vivo anti-oxidant activities using standardized methods, as reported previously ${ }^{36}$; and 3). Published in the last 10 years (2011-2021) and written in English or Indonesian Language. Studies that only determined total phenolic compounds were not included. Editorials, reviews, commentaries, case reports, book or book chapter were excluded.

\section{Database and search strategy}

The search was conducted in May 29, 2021 through search engines of the following databases: Embase, Medline, BMJ, Web of Science, Science Direct, Cochrane, and PubMed. The terms combination used to search in the title, abstract, and keywords was "((cascara coffee) OR (coffee husk) OR (coffee pulp) OR (coffee waste)) AND ((antioxidant) OR (photoaging))".

\section{Study selection and data extraction}

A reference manager (EndNote X9, Thompson Reuters, Philadelphia, PA, USA) was used to import the list of references from all databases, where duplicates were then removed. The two-steps selection was carried out by firstly remove the non-eligible article by screening the titles and abstract from the collected references. Secondly, two authors WL and SS conducted the screening of the full texts according to the stated inclusion criteria and data availability. The data were extracted from main articles and their supplementary materials, whenever required. The extracted data included the report characteristics (author/s, publication year), type of specimen (coffee husk, coffee silverskin, coffee pulp, coffee parchment or cascara), processing methods (pre-treatment and extraction), and outcomes (antioxidant activity and others).

\section{Results}

Study eligibility results

The search yielded 850 records from the stated databases (Figure 1), where as many as 170 duplicates were removed. The duplicate removal left 680 articles to undergo the first screening, of which, 616 studies were potentially eligible. Second screening excluded 597 articles, resulting the final 19 articles for qualitative synthesis. 


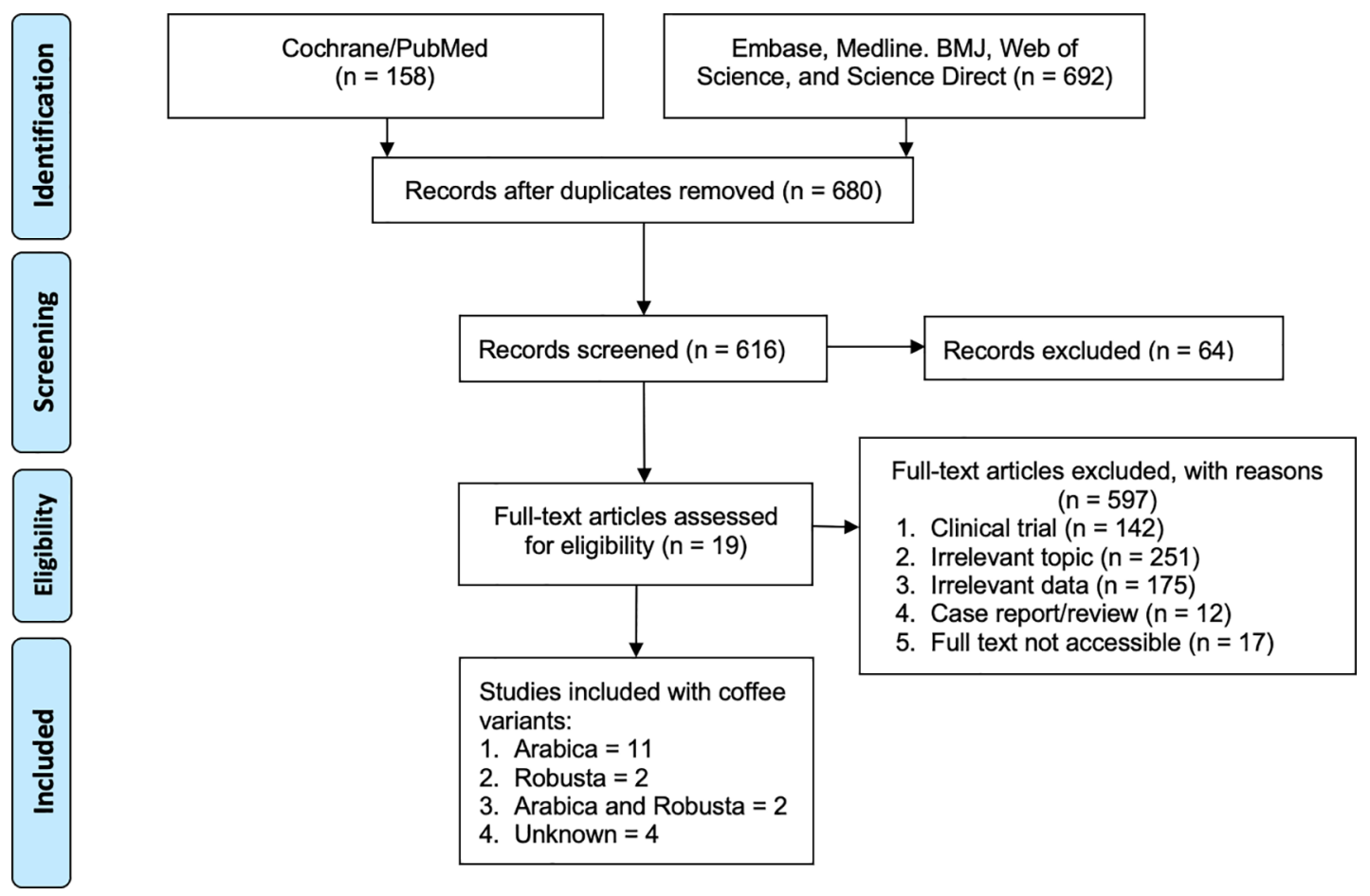

Figure 1. Schematic diagram of the literature search according to PRISMA.

Most of the studies produced crude extract using water, ${ }^{22,37,44}$ followed by extraction using polar extracts (such as methanol and ethanol) $)^{38,40,45,46}$ and non-polar extract (n-hexane). ${ }^{47} \mathrm{~A}$ study, in particular, used supercritical fluid extraction with $\mathrm{CO}_{2}$ as the solvent. ${ }^{48}$

\section{Antioxidant properties of coffee by-products}

The investigations of antioxidant activities were varied in each study, but mostly, DPPH assay was employed (Table 1). ${ }^{6,22,40,44-46,48,52}$ Based on DPPH assay, the $\mathrm{IC}_{50}$ reached as low as $5.8 \mathrm{ppm}$ obtained in the lotion product made of coffee pulp extract using ethanol and water solvent. ${ }^{46}$ However, the value is hard to compare since other studies did not report the $\mathrm{IC}_{50}$ and used different methods. Other antioxidant assays included FRAP, ${ }^{37,38,42,43}$ ABTS $,{ }^{38,43,45,49,53}{ }^{N O},{ }^{45,47}$ ORAC $^{42,51}$ and Folin-Ciocalteu. ${ }^{45}$ Pre-treatments such as fermentation, ${ }^{47,50}$ vacuum drying, ${ }^{52}$ sun-drying, ${ }^{37}$ and lipophilization ${ }^{42,49}$ were found to yield the optimum value of antioxidant capacity. Other than crude extract, the reports also investigated the antioxidant properties of products made by coffee cascara such as dietary fiber, ${ }^{53}$ instant beverage powder ${ }^{43}$ lotion, ${ }^{46}$ fodder, ${ }^{37}$ anthocyanin, ${ }^{44}$ and essential oil. ${ }^{6,51}$

\section{Discussion}

Treated as a solid waste in coffee industry, coffee by product could be a threat to the environment, especially to the aquatic organisms. ${ }^{7}$ Nonetheless, they could be used as the source of antioxidant into various food and beverage products, viz tea, ${ }^{43,54,55}$ dietary fiber, ${ }^{56,57}$ food preservatives, ${ }^{58,59}$ wheat flour substitute, ${ }^{60}$ and food additives. ${ }^{61,62}$ Consumption of foods or beverages derived from coffee by-products has been associated to its health benefits owing to the rich presence of bioactive compounds. Phenolic compounds and caffein have been reported contained in the coffee pulp of arabica and robusta variants. ${ }^{63}$ Phenolic compounds in high concentrations might also be retrieved from arabica coffee silverskin. ${ }^{64}$

A study comparing robusta and arabica coffee pulp with aqueous extraction revealed higher antioxidant capacity in that of arabica variant. ${ }^{22}$ However, a different result was shown by another study comparing the antioxidant activities of coffee silverskin from both variants. The study found that coffee silverskin from robusta variant has higher antioxidant activity as suggested by DPPH, ABTS, and FRAP assays. ${ }^{65}$ Higher antioxidant efficacies of robusta variant were also revealed by a study employing green coffee extract. ${ }^{66}$ Antioxidant activities could be affected not only by the variant, but also the extraction or brewing method. ${ }^{67}$ Additionally, each coffee by-product could have different levels of antioxidant activity, where coffee silverskin was revealed to have the highest value. ${ }^{53}$ 
Table 1. Antioxidant properties of coffee by-products.

\begin{tabular}{|c|c|c|c|c|c|}
\hline Year & By-product & Processing & $\begin{array}{l}\text { Antioxidant } \\
\text { properties* }\end{array}$ & Others & Reference \\
\hline 2018 & $\begin{array}{l}\text { Arabica coffee } \\
\text { husk }\end{array}$ & $\begin{array}{l}\text { Hydrodistillation } \\
\text { extraction to } \\
\text { obtain essential } \\
\text { oil }\end{array}$ & $84.60 \%$ at $100 \mathrm{ppm}^{\mathrm{a}}$ & $\begin{array}{l}\text { The oil was dominated by } \\
\text { aromatic compounds, in } \\
\text { which } 30 \% \text { and } 40 \% \text { of the } \\
\text { total compounds were } \\
\text { hydrocarbon and oxygenated } \\
\text { constituents, respectively. }\end{array}$ & 6 \\
\hline 2018 & $\begin{array}{l}\text { Arabica coffee } \\
\text { pulp }\end{array}$ & $\begin{array}{l}\text { Ensiling and sun- } \\
\text { drying to obtain } \\
\text { fodder }\end{array}$ & $\begin{array}{l}>2,5 \mu \mathrm{mol} \\
\mathrm{TE}^{-1} \mathrm{~mL}^{\mathrm{b}}\end{array}$ & $\begin{array}{l}\text { Ensiled sun-dried coffee pulp } \\
\text { has the highest crude protein, } \\
\text { neutral detergent fiber, and } \\
\text { acid detergent fiber }\end{array}$ & 37 \\
\hline 2019 & $\begin{array}{l}\text { Arabica and } \\
\text { robusta coffee } \\
\text { pulp }\end{array}$ & $\begin{array}{l}\text { Extraction using } \\
\text { water at different } \\
\text { temperatures }\end{array}$ & $33.5 \%$ at $100 \mathrm{ppm}^{\mathrm{a}}$ & $\begin{array}{l}\text { Best phenolic content was } \\
\text { obtained at } 85^{\circ} \mathrm{C} \\
\text { Best antioxidant activities } \\
\text { were obtained at } 75^{\circ} \mathrm{C} \\
\text { Antibacterial activities of } \\
\text { arabica are better than } \\
\text { robusta }\end{array}$ & 22 \\
\hline 2020 & $\begin{array}{l}\text { Robusta coffee } \\
\text { pulp }\end{array}$ & $\begin{array}{l}\text { Hot air drying, } \\
\text { vacuum drying } \\
\text { and low } \\
\text { temperature and } \\
\text { pressure drying }\end{array}$ & $\begin{array}{l}\text { Antioxidant capacity } \\
\text { (mg TE/g DW): } \\
21.39^{\mathrm{c}}, 2.24^{\mathrm{a}} \text {, and } \\
16.73^{\mathrm{b}}\end{array}$ & $\begin{array}{l}\text { Vacuum drying is the } \\
\text { optimum method, resulting } \\
\text { the highest contents of } \\
\text { phenolics, caffeine, gallic acid, } \\
\text { and proanthocyanins. }\end{array}$ & 52 \\
\hline 2020 & $\begin{array}{l}\text { Arabica coffee } \\
\text { husk }\end{array}$ & $\begin{array}{l}\text { Extraction using } \\
\text { water, ethanol, } \\
\text { and combination } \\
\text { of water and } \\
\text { ethanol }\end{array}$ & $\begin{array}{l}\text { Antioxidant capacity } \\
\text { at } 100 \text { ppm: } \\
84.95 \% \%^{\mathrm{a}}, 97.21 \%^{\mathrm{c}}, \\
\text { and } 3136.4 \mu \mathrm{mol} \\
\text { TE/g }\end{array}$ & $\begin{array}{l}\text { Water bath with water and } \\
\text { ethanol (1:1) extraction } \\
\text { yielded the highest bioactive } \\
\text { compounds (phenolics, } \\
\text { flavonoids, and tannins). }\end{array}$ & 38 \\
\hline 2017 & $\begin{array}{l}\text { Arabica coffee } \\
\text { pulp }\end{array}$ & $\begin{array}{l}\text { Extraction using } \\
\text { water }\end{array}$ & $\begin{array}{l}51-92 \mu \mathrm{mol} \mathrm{TE} / \mathrm{g} \\
\mathrm{DM}^{\mathrm{C}}\end{array}$ & $\begin{array}{l}\text { The caffeine amounting up to } \\
226 \mathrm{mg} / \mathrm{L} \text { and total } \\
\text { polyphenols - } 283 \mathrm{mg} \text { GAE/L }\end{array}$ & 39 \\
\hline 2011 & $\begin{array}{l}\text { Arabica coffee } \\
\text { husk and coffee } \\
\text { ground }\end{array}$ & $\begin{array}{l}\text { Supercritical } \\
\text { fluid extraction } \\
\text { (SFE) using } \mathrm{CO}_{2} \\
\text { and } \mathrm{CO}_{2} \text { with } \\
\text { co-solvent }\end{array}$ & $\mathrm{IC}_{50}>250 \mu \mathrm{g} / \mathrm{mL}^{\mathrm{a}}$ & $\begin{array}{l}\text { The best method is low } \\
\text { pressure extraction. } \\
\text { Dominating compounds of } \\
\text { the extract include caffeine } \\
\text { and chlorogenic acid. }\end{array}$ & 48 \\
\hline 2015 & Coffee husk & $\begin{array}{l}\text { Extraction using } \\
\text { combination of } \\
\text { methanol, } \\
\text { ethanol or water }\end{array}$ & $\begin{array}{l}\mathrm{IC}_{50}<25 \mu \mathrm{g} / \mathrm{mL}^{\mathrm{a}} \\
\mathrm{IC}_{50}<30 \mu \mathrm{g} / \mathrm{mL}^{\mathrm{b}}\end{array}$ & $\begin{array}{l}\text { Samples extracted using } \\
\text { methanol }(50 \%) \text { has the } \\
\text { highest phenolic contents and } \\
\text { antioxidant activity. }\end{array}$ & 40 \\
\hline 2020 & $\begin{array}{l}\text { Arabica coffee } \\
\text { pulp }\end{array}$ & $\begin{array}{l}\text { Isolation of } \\
\text { volatile and non- } \\
\text { volatile } \\
\text { compounds }\end{array}$ & $\begin{array}{l}35.8 \mu \mathrm{mol} \mathrm{TE} / \mathrm{g}^{\mathrm{a}} \\
12.23 \mu \mathrm{mol} \mathrm{TE} / \mathrm{g}^{\mathrm{e}}\end{array}$ & $\begin{array}{l}151 \text { volatile compounds had } \\
\text { been obtained (mainly } \\
\text { alcohols, acids, ketones, and } \\
\text { esters) }\end{array}$ & 51 \\
\hline 2020 & $\begin{array}{l}\text { Robusta coffee } \\
\text { pulp }\end{array}$ & $\begin{array}{l}\text { Extraction of free } \\
\text { and bound } \\
\text { phenolics using } \\
\text { ethanol and } \\
\text { combination of } \\
\text { ethanol and ethyl } \\
\text { acetate, } \\
\text { respectively }\end{array}$ & $\begin{array}{l}\mathrm{IC}_{50}=12.75 \mu \mathrm{g} / \mathrm{mL}^{\mathrm{a}} \\
\mathrm{IC}_{50}=30.76 \mu \mathrm{g} / \mathrm{mL}^{\mathrm{c}} \\
6.38 \mathrm{M} \mathrm{TE} / 100 \mathrm{~g}^{\mathrm{b}}\end{array}$ & $\begin{array}{l}\text { The coffee pulp extract could } \\
\text { be used as the source of pectin } \\
\text { and polyphenols with good } \\
\text { antioxidant activities }\end{array}$ & 45 \\
\hline 2018 & $\begin{array}{l}\text { Arabica coffee } \\
\text { pulp }\end{array}$ & $\begin{array}{l}\text { Extraction using } \\
\text { combination of } \\
\text { water and } \\
\text { ethanol }\end{array}$ & $\begin{array}{l}44.49 \mathrm{mg} \mathrm{GAE} / \mathrm{g}^{\mathrm{f}} \\
141.7 \mu \mathrm{mol} \mathrm{TE} / \mathrm{g}^{\mathrm{a}}\end{array}$ & $\begin{array}{l}\text { The coffee pulp extracts } \\
\text { reduce the production of IL- } 8 \\
\text { in gastric epithelial cells. }\end{array}$ & 45 \\
\hline 2019 & $\begin{array}{l}\text { Arabica coffee } \\
\text { pulp }\end{array}$ & $\begin{array}{l}\text { Phenolic } \\
\text { extraction using } \\
\text { water or } \mathrm{HCl} 1 \%\end{array}$ & $\begin{array}{l}57087.8 \mu \mathrm{mol} \\
\text { TE/100g } 806.93 \mathrm{mg} \\
\text { AEAC/100g }\end{array}$ & $\begin{array}{l}\text { Extraction using } \mathrm{HCl} \text { yielded } \\
\text { the best overall activities }\end{array}$ & 42 \\
\hline
\end{tabular}


Table 1. Continued

\begin{tabular}{|c|c|c|c|c|c|}
\hline Year & By-product & Processing & $\begin{array}{l}\text { Antioxidant } \\
\text { properties* }\end{array}$ & Others & Reference \\
\hline 2020 & Arabica cascara & $\begin{array}{l}\text { Freeze-dried } \\
\text { aqueous extract } \\
\text { of coffee cascara }\end{array}$ & $\begin{array}{l}82.85 \mathrm{mq} \text { eq. } \\
\mathrm{CGA} / \mathrm{m} \mathrm{L}^{\mathrm{C}} \\
1.08 \mathrm{mg} \mathrm{eq}^{\text {eq. }} \\
\mathrm{CGA} / \mathrm{mL}^{\mathrm{b}}\end{array}$ & $\begin{array}{l}\text { Melanoidins were correlated } \\
\text { to the color of infused cascara } \\
\text { beverage. } \\
\text { The instant cascara beverage } \\
\text { has low acrylamide and } \\
\text { caffeine levels with many } \\
\text { antioxidants and nutrients. }\end{array}$ & 43 \\
\hline 2012 & Coffee pulp & $\begin{array}{l}\text { Anthocyanin } \\
\text { purification } \\
\text { using column } \\
\text { extraction }\end{array}$ & $90 \%$ at $200 \mathrm{ppm}^{\mathrm{a}}$ & $\begin{array}{l}\text { The anthocyanin could be } \\
\text { retrieved from coffee pulp to } \\
\text { produce food colorants and } \\
\text { bioactive ingredients }\end{array}$ & 44 \\
\hline 2020 & Coffee pulp & $\begin{array}{l}\text { Fermentation of } \\
\text { coffee pulp using } \\
\text { indigenous lactic } \\
\text { acid bacteria }\end{array}$ & $42.6 \%$ at $100 \mathrm{ppm}^{\mathrm{a}}$ & $\begin{array}{l}\text { Fermentation using } \\
\text { indigenous lactic acid } \\
\text { produced coffee pulp with } \\
\text { higher antioxidant activity }\end{array}$ & 50 \\
\hline 2020 & Coffee pulp & $\begin{array}{l}\text { Extraction using } \\
\text { ethanol: water } \\
\text { solvent to } \\
\text { produce lotion }\end{array}$ & $\mathrm{IC}_{50}=5.8 \mathrm{ppm}^{\mathrm{a}}$ & $\begin{array}{l}\text { The stability and antioxidant } \\
\text { activity of the lotion } \\
\text { containing coffee pulp extract } \\
\text { were higher in comparison to } \\
\text { the commercial product. }\end{array}$ & 46 \\
\hline 2016 & $\begin{array}{l}\text { Arabica coffee } \\
\text { pulp }\end{array}$ & $\begin{array}{l}\text { Drying and } \\
\text { blending } \\
\text { followed by } \\
\text { aqueous } \\
\text { extraction and } \\
\text { lyophilization }\end{array}$ & $\begin{array}{l}\mathrm{IC}_{50}=82 \mu \mathrm{g} / \mathrm{mL}^{\mathrm{a}} \\
\mathrm{IC}_{50}=18 \mu \mathrm{g} / \mathrm{mL}^{\mathrm{c}}\end{array}$ & $\begin{array}{l}\text { Possessing antibacterial } \\
\text { activity against gram-positive } \\
\text { and negative bacteria. }\end{array}$ & 49 \\
\hline 2010 & $\begin{array}{l}\text { Arabica and } \\
\text { robusta coffee } \\
\text { pulp, husk, } \\
\text { parchment } \\
\text { husk, silverskin, } \\
\text { and coffee } \\
\text { ground }\end{array}$ & $\begin{array}{l}\text { Isolation of } \\
\text { dietary fiber }\end{array}$ & $2.12 \mathrm{mmol} \mathrm{TE} / 100 \mathrm{~g}^{\mathrm{c}}$ & $\begin{array}{l}\text { Dietary fiber retrieved from } \\
\text { coffee by-products is rich with } \\
\text { bioactive compounds and } \\
\text { high antioxidant activity. }\end{array}$ & 53 \\
\hline 2011 & $\begin{array}{l}\text { Arabica coffee } \\
\text { pulp }\end{array}$ & $\begin{array}{l}\text { Fermentation } \\
\text { using Aspergillus } \\
\text { tamarii, followed } \\
\text { by hexane } \\
\text { extraction }\end{array}$ & $\begin{array}{l}\mathrm{ED}_{50}=0.034 \mathrm{mg}^{\mathrm{d}} \\
\mathrm{t}_{\mathrm{ED} 50}=1.12 \text { minutes }\end{array}$ & $\begin{array}{l}\text { Higher antioxidant activity in } \\
\text { the fermented coffee pulp }\end{array}$ & 47 \\
\hline
\end{tabular}

GAE: gallic acid equivalent; TE: Trolox equivalent.

*The most optimal value from the obtained product.

Determined by ${ }^{\mathrm{a}}$ 2,2-diphenyl-1-picrylhydrazyl (DPPH) assay; ${ }^{b}$ ferric reducing antioxidant power (FRAP) assay; ${ }^{\mathrm{C}} 2, \mathrm{2}^{\prime}$-azino-bis (3-ethylben-

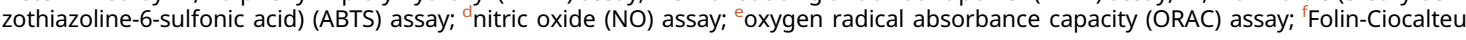
assay.

Water has been a common solvent used on coffee by products, as reported by many researches. ${ }^{22,39,43,52}$ This due to the fact that aqueous extraction is the most practical processing method of obtaining antioxidant compounds. Moreover, it may also attract polar and semi-polar compounds such as phenolic acids, flavonoids, and so on. ${ }^{68,69}$ Other studies combined water with methanol or ethanol which can increase the affinity of the solvent with that of semi-polar compounds. ${ }^{38,40,45,46}$ Most of these studies yielded extracts with strong antioxidants $\left(\mathrm{IC}_{50}<50 \mu \mathrm{g} / \mathrm{mL}\right){ }^{40,45,46,49}$ Lipophilization using $\mathrm{HCl}$ or $\mathrm{NaOH}$ had been proven to yield higher amount of bioactive compounds and, as a consequence, increased the antioxidant properties. The antioxidant activity could also be improved by fermentation process using proper bacteria. ${ }^{47,50}$ Nonetheless, extraction using more sophisticated solvent, such as supercritical $\mathrm{CO}_{2}$, did not contribute to higher anti-oxidant activity $\left(\mathrm{IC}_{50}>250 \mu \mathrm{g} / \mathrm{mL}\right){ }^{48}$

Since coffee by-products contain nutrients and antioxidants, they might be used as food additives or animal food sources. Simple ensiling and sun-drying were sufficient to produce fodder with high protein and fiber possessing antioxidant capacity as high as $2.5 \mu \mathrm{mol} \mathrm{TE}{ }^{-1} \mathrm{~mL} .{ }^{37}$ Dietary fiber had been isolated from various coffee by-products of both robusta and arabica variant containing bioactive compounds and high antioxidant activity. ${ }^{53}$ Coffee by-products could also be used as food odorants and dye. ${ }^{6,44,51}$ Beverage powder made of arabica cascara was proven to contain high amount of nutrients and antioxidant activity. ${ }^{43}$ The use of coffee by-product in topical formulation, such as lotion, had been reported as well. ${ }^{46}$ 
Phenolics, flavonoids, and tannins are among the common compounds found in aqueous extracts of coffee husks, coffee pulp, and coffee, silverskin, ${ }^{22,38}$ which are identical to coffee bean. ${ }^{70,71}$ Caffeine, gallic acid, and proanthocyanidins were also contained in the by-products, ${ }^{48,52}$ contributing to the antioxidant efficacies. ${ }^{72}$ Tannins could prevent the oxidative stress, oxidative damage, and UVB-induced matrix metalloproteinase- $1 .{ }^{73}$ Coffee cascara was reported to possess 8 times higher anti-radical capacity compared to blueberry with anti-cancer and vitality booster properties. ${ }^{52}$ Other health benefits of coffee by-products could be attributed to their rich fiber, magnesium, calcium, and vitamin $\mathrm{C}$, and low fat content. ${ }^{24}$ Additionally, coffee cascara was also known to contain pectin which can be used as food additive. ${ }^{45}$ The aqueous extract of arabica coffee pulp could inhibit the production of IL-8 in gastric epithelial cells. ${ }^{45}$ Antibacterial properties of coffee cascara, coffee silverskin, and coffee husk have been reported as well. ${ }^{6,22,49}$

Bread made of coffee husk and coffee silverskin was reported free of gluten, carrying an antioxidant, $\alpha$ glucosidase inhibitor, which is potential to reduce chronic diseases, oxidative stress, cholesterol level, and post prandial blood glucose level. ${ }^{74}$ Arabica coffee pulp yielded high antibacterial activity against nosocomial bacteria; Staphylococcus Epidermidis and Pseudomonas Aeruginosa. ${ }^{75}$ Fermented coffee pulp had high phenolic compounds and with pH level and total acid level. ${ }^{76}$ Phenolic compounds are useful in reducing inflammation-associated cholesterol via adipogenesis inhibition. ${ }^{77}$ Anti-cholesterol properties of coffee by-product was reported to effectively decrease the cholesterol level by inhibiting the absorbance of colonic cholesterol. ${ }^{75}$

\section{Conclusions}

Coffee by-products relatively have high antioxidant activities, depending on the processing method and variant. Other than antioxidants, they are rich in fiber and nutrients making them as potential additives in multiple products. Despite their high antioxidant activity and polyphenol content, the utilization of coffee by-products in topical formulation is relatively scarce compared to that in foods or beverages. Furthermore, investigation using different assays and parameters making it difficult to compare the results from each research. Hence, we recommend using robust and uniform methods in determining the antioxidant activity of coffee by-products.

\section{Data availability}

Underlying data

All data underlying the results are available as part of the article and no additional source data are required.

\section{Reporting guidelines}

Figshare: PRISMA checklist for 'Coffee by-products as the source of antioxidants: a systematic review'. DOI: https://doi. org/10.6084/m9.figshare.18866456.

Data are available under the terms of the Creative Commons Attribution 4.0 International license (CC-BY 4.0).

\section{Conflict of interest}

The authors declare that they have no conflict of interest.

\section{Ethics statement}

Not required.

\section{Acknowledgement}

Authors would like to thank Postgraduate Program, School of Medicine, Universitas Syiah Kuala in assisting the during writing processes.

\section{References}

1. Zainura $U$, Kusnadi N Burhanuddin B: Perilaku Kewirausahaan Petani Kopi Arabika Gayo di Kabupaten Bener Meriah Provins Aceh. Jurnal Penyuluhan. 2016; 12(2): 126. Publisher Full Text

2. Juliaviani N, Sahara WR: Transmisi Harga Kopi Arabika Gayo di Provinsi Aceh. Jurnal Agribisnis Indonesia. 2017; 5(1): 39-56.

Publisher Full Tex
3. Moreira MD, Melo MM, Coimbra JM, et al.: Solid coffee waste as alternative to produce carotenoids with antioxidant and antimicrobial activities. Waste Manag. $2018 \mathrm{Dec} ; 82$ : 93-99. PubMed Abstract | Publisher Full TextEpub 2018/12/05.

4. Yun BY, Cho HM, Kim YU, et al.: Circular reutilization of coffee waste for sound absorbing panels: A perspective on material recycling. Environ. Res. 2020 2020/05/01/; 184: 109281. PubMed Abstract | Publisher Full Text 
5. Hejna A: Potential applications of by-products from the coffee industry in polymer technology - Current state and perspectives. Waste Manag. 2021 Feb 15; 121: 296-330. PubMed Abstract | Publisher Full TextEpub 2021/01/07.

6. Yousef HMA, Amina M: Essential oil of Coffee arabica L. husks: a brilliant source of antimicrobial and antioxidant agents. Biomed. Res. 2018; 29(1).

Publisher Full Text

7. Thenepalli T, Ramakrishna C, Ahn JW: Environmental Effect of the Coffee Waste and Anti-Microbial Property of Oyster Shell Waste Treatment. J. Energy Eng. 2017; 26(2): 39-49. Publisher Full Text

8. Nguyen QA, Cho E, Trinh LTP, et al.: Development of an integrated process to produce d-mannose and bioethanol from coffee residue waste. Bioresour. Technol. 2017 2017/11/01/; 244: 1039-1048.

PubMed Abstract | Publisher Full Text

9. Battista F, Fino D, Mancini G: Optimization of biogas production from coffee production waste. Bioresour. Technol. 2016 2016/01/01/; 200: 884-890.

PubMed Abstract | Publisher Full Text

10. Hoseini M, Cocco S, Casucci C, et al.: Coffee by-products derived resources. A review. Biomass Bioenergy. 2021; 148: 106009. Publisher Full Text

11. San Martin $D$, Orive $M$, Iñarra $B$, et al.: Spent coffee ground as second-generation feedstuff for dairy cattle. Biomass Conversion and Biorefinery. 2020; 11(2): 589-599.

Publisher Full Text

12. Klingel T, Kremer JI, Gottstein V, et al.: A Review of Coffee By-Products Including Leaf, Flower, Cherry, Husk, Silver Skin, and Spent Grounds as Novel Foods within the European Union. Foods. 2020 May 21; 9(5)

PubMed Abstract | Publisher Full Text | Free Full TextEpub 2020/05/28.

13. Pandey A, Soccol CR, Nigam P, et al.: Biotechnological potential of coffee pulp and coffee husk for bioprocesses. Biochem. Eng. J. 2000; 6(2): 153-162.

PubMed Abstract | Publisher Full Text

14. Marcelinda A, Ridhay A, Prismawiryanti.: The Atioxidant Activity of Husk Coffea (Coffea sp.) Extract Base on Various Levels of Polar Solvent. Online J. Nat. Sci. 2016; 15(1): 21-30.

15. Tiwari P: Phenolics and flavonoids and antioxidant potential of balarishta prepared by traditional and modern methods. Asian J. Pharm. Anal. 2014; 4: 5-10.

16. Sankpal S, Pathade KS, Kondawar M: Coffea arabica: Herbal drug on Global health issue-obesity. Research Journal of Pharmacognosy and Phytochemistry. 2020; 12(4): 201-206.

17. Sameer SJ, Vijay RS, Chandrakant SM: Daily consumption of antioxidants:-prevention of disease is better than cure. Asian J. Pharm. Res. 2013; 3(1): 34-40.

18. Narasimhan R: Phytochemical Screening and Antioxidant Studies in the Pulp Extracts of Cucurbita maxima. Asian J. Pharm. Res. 2016; 6(1): 2053-2055.

Publisher Full Text

19. Kushwaha SP, Rawat SK, Kumar P, et al.: Coupling antioxidant and antidiabetic assets of 2, 4-thiazolidinedione derivatives. Asian Journal of Pharmaceutical Analysis. 2011; 1(4): 71-73.

20. Deepthi B, Muthuprasanna P: Effect of Surfactant on Extraction of Caffeine from Coffee Powder. Research Journal of Pharmacognosy and Phytochemistry. 2012; 4(5): 271-276.

21. Oliveira LS, Franca AS: Chapter 31 - An Overview of the Potential Uses for Coffee Husks. Preedy VR, editor. Coffee in Health and Disease Prevention. San Diego: Academic Press; 2015; p. 283-291.

22. Sholichah E, Apriani R, Desnilasari D, et al.: By-Product of Arabica and Robusta Coffee husk as Polyphenol Source for Antioxidant and Antibacterial. Jurnal Industri Hasil Perkebunan. 2019; 14(2): 57-66.

Publisher Full Text

23. Esquivel $P$, Jiménez VM: Functional properties of coffee and coffee by-products. Food Res. Int. 2012; 46(2): 488-495. Publisher Full Text

24. Murthy PS, Madhava NM: Sustainable management of coffee industry by-products and value addition-A review. Resour. Conserv. Recycl. 2012 2012/09/01/; 66: 45-58. Publisher Full Text

25. Volz RK, McGhie TK, Kumar S: Variation and genetic parameters of fruit colour and polyphenol composition in an apple seedling population segregating for red leaf. Tree Genet. Genomes. 2014 2014/08/01; 10(4): 953-964 Publisher Full Text

26. Pandel R, Poljsak B, Godic A, et al.: Skin photoaging and the role of antioxidants in its prevention. ISRN Dermatol. 2013 Sep 12; 2013:
930164

PubMed Abstract | Publisher Full Text | Free Full Text

27. Petruk G, Del Giudice R, Rigano MM, et al.: Antioxidants from Plants Protect against Skin Photoaging. Oxidative Med. Cell. Longev. 2018; 2018: 1454936

PubMed Abstract | Publisher Full Text | Free Full Text

28. Tuong W, Walker L, Sivamani RK: Polyphenols as novel treatment options for dermatological diseases: A systematic review of clinical trials. J. Dermatolog. Treat. 2015; 26(4): 381-8. PubMed Abstract

29. Socas-Rodríguez B, Álvarez-Rivera G, Valdés A, et al.: Food by-products and food wastes: are they safe enough for their valorization? Trends Food Sci. Technol. 2021 2021/08/01/; 114: 133-147. Publisher Full Text

30. Janissen B, Huynh T: Chemical composition and value-adding applications of coffee industry by-products: A review. Resour. Conserv. Recycl. 2018 2018/01/01/; 128: 110-117.

Publisher Full Text

31. Gemechu FG: Embracing nutritional qualities, biological activities and technological properties of coffee byproducts in functional food formulation. Trends Food Sci. Technol. 2020 2020/10/01/; 104: 235-261.

Publisher Full Text

32. da Silveira JS, Mertz C, Morel G, et al.: Alcoholic fermentation as a potential tool for coffee pulp detoxification and reuse: Analysis of phenolic composition and caffeine content by HPLC-DAD-MS/ MS. Food Chem. 2020 2020/07/30/; 319: 126600.

PubMed Abstract | Publisher Full Text

33. Moher D, Liberati A, Tetzlaff J, et al.: Preferred reporting items for systematic reviews and meta-analyses: The PRISMA statement. PLoS Med. 2009 Jul; 6(7): e1000097.

PubMed Abstract | Publisher Full Text

34. Fajar JK, Ilmawan M, Mamada S, et al.: Global prevalence of persistent neuromuscular symptoms and the possible pathomechanisms in COVID-19 recovered individuals: A systematic review and meta-analysis. Narra J. 2021; 1(3): e48. Publisher Full Text

35. Fahriani M, Ilmawan M, Fajar JK, et al.: Persistence of long COVID symptoms in COVID-19 survivors worldwide and its potential pathogenesis-a systematic review and meta-analysis. Narra J. 2021; 1(2): e36. Publisher Full Text

36. Munteanu IG, Apetrei C: Analytical Methods Used in Determining Antioxidant Activity: A Review. Int. J. Mol. Sci. 2021 Mar 25; 22(7). PubMed Abstract | Publisher Full Text | Free Full Text

37. Ameca GM, Cerrilla MEO, Córdoba PZ, et al.: Chemical composition and antioxidant capacity of coffee pulp. Ciência e Agrotecnologia. 2018; 42(3): 307-313. Publisher Full Text

38. Silva MO, Honfoga JNB, Medeiros LL, et al.: Obtaining Bioactive Compounds from the Coffee Husk (Coffea arabica L.) Using Different Extraction Methods. Molecules. 2020 Dec 24; 26(1). PubMed Abstract | Publisher Full Text | Free Full Text

39. Heeger A, Kosiń ska-Cagnazzo A, Cantergiani E, et al.: Bioactives of coffee cherry pulp and its utilisation for production of Cascara beverage. Food Chem. 2017 2017/04/15/; 221: 969-975. PubMed Abstract | Publisher Full Text

40. Vijayalaxmi S, Jayalakshmi SK, Sreeramulu K: Polyphenols from different agricultural residues: extraction, identification and their antioxidant properties. J. Food Sci. Technol. 2015; 52(5): 2761-2769.

PubMed Abstract | Publisher Full Text

41. Magoni C, Bruni I, Guzzetti L, et al.: Valorizing coffee pulp by-products as anti-inflammatory ingredient of food supplements acting on IL-8 release. Food Res. Int. 2018 2018/10/01/; 112: 129-135.

PubMed Abstract | Publisher Full Text

42. Delgado SR, Arbelaez AFA, Rojano B: Antioxidant capacity, bioactive compounds in coffee pulp and implementation in the production of infusions. Acta Sci. Pol. Technol. Aliment. 2019 Jul-Sep; 18(3): 235-248.

PubMed Abstract | Publisher Full Text

43. Iriondo-DeHond $\mathrm{A}$, Elizondo AS, Iriondo-DeHond $\mathrm{M}$, et al.: Assessment of Healthy and Harmful Maillard Reaction Products in a Novel Coffee Cascara Beverage: Melanoidins and Acrylamide. Foods. 2020; 9(5). PubMed Abstract | Publisher Full Text

44. Murthy PS, Manjunatha MR, Sulochannama G, et al.: Extraction, Characterization and Bioactivity of Coffee Anthocyanins. Eur. J. Biol. Sci. 2012; 4(1): 13-19.

45. Manasa V, Padmanabhan A, Anu Appaiah KA: Utilization of coffee pulp waste for rapid recovery of pectin and polyphenols fo 
sustainable material recycle. Waste Manag. 2021 Feb 1; 120 762-771.

PubMed Abstract | Publisher Full Text

46. Widiputri DI, Wijaya S, Kusumocahyo SP: Development of Skin Lotion Containing Antioxidant Extract from Coffee Pulp and Study on Its Stability. IOP Conference Series: Materials Science and Engineering. 2020; 742: 012020.

Publisher Full Text

47. Arellano-González MA, Ramírez-Coronel MA, Torres-Mancera MT, et al.: Antioxidant Activity of Fermented and Nonfermented Coffee (Coffea arabica.) Pulp Extracts. Food Technol. Biotechnol. 2011; 49(3): 374-378.

48. Andrade KS, Gonçalvez RT, Maraschin M, et al.: Supercritical fluid extraction from spent coffee grounds and coffee husks: Antioxidant activity and effect of operational variables on extract composition. Talanta. 2012 2012/01/15/; 88: 544-552. PubMed Abstract | Publisher Full Text

49. Duangjai A, Suphrom N, Wungrath J, et al.: Comparison of antioxidant, antimicrobial activities and chemical profiles of three coffee (Coffea arabica L.) pulp aqueous extracts. Integr. Med. Res. 2016 Dec; 5(4): 324-331.

PubMed Abstract | Publisher Full Text | Free Full Text

50. Oktaviani L, Astuti DI, Rosmiati M, et al.: Fermentation of coffee pulp using indigenous lactic acid bacteria with simultaneous aeration to produce cascara with a high antioxidant activity. Heliyon. 2020 Jul; 6(7): e04462.

PubMed Abstract | Publisher Full Text | Free Full Text

51. Pua A, Choo WXD, Goh RMV, et al.: A systematic study of key odourants, non-volatile compounds, and antioxidant capacity of cascara (dried Coffea arabica pulp). LWT. 2021 2021/03/01/; 138: 110630.

Publisher Full Text

52. Kieu Tran TM, Kirkman T, Nguyen M, et al.: Effects of drying on physical properties, phenolic compounds and antioxidant capacity of Robusta wet coffee pulp (Coffea canephora). Heliyon. 2020 Jul; 6 (7): e04498.

PubMed Abstract | Publisher Full Text | Free Full Text

53. Murthy PS, Naidu MM: Recovery of Phenolic Antioxidants and Functional Compounds from Coffee Industry By-Products. Food Bioprocess Technol. 2010; 5(3): 897-903.

54. Heeger A, Kosinska-Cagnazzo A, Cantergiani E, Andlauer W: Bioactives of coffee cherry pulp and its utilisation for production of Cascara beverage. Food Chem. 2017 Apr 15; 221: 969-975.

PubMed Abstract | Publisher Full Text

55. Martinez-Saez N, Ullate M, Martin-Cabrejas MA, et al.: A novel antioxidant beverage for body weight control based on coffee silverskin. Food Chem. 2014 May 1; 150: 227-234. PubMed Abstract | Publisher Full Text

56. Rios MB, Iriondo-DeHond $A$, Iriondo-DeHond $M$, et al.: Effect of Coffee Cascara Dietary Fiber on the Physicochemical, Nutritional and Sensory Properties of a Gluten-Free Bread Formulation. Molecules. 2020 Mar 17; 25(6). PubMed Abstract | Publisher Full Text | Free Full Text

57. Iriondo-DeHond A, Aparicio García N, Fernandez-Gomez B, et al.: Validation of coffee by-products as novel food ingredients. Innovative Food Sci. Emerg. Technol. 2019; 51: 194-204. Publisher Full Text

58. Sofía Torres-Valenzuela L, Andrea Serna-Jiménez J, Martínez K: Coffee By-Products: Nowadays and Perspectives. Coffee Production and Research. 2020.

Publisher Full Text

59. Sampaio A, Dragone $G$, Vilanova $M$, et al.: Production, chemical characterization, and sensory profile of a novel spirit elaborated from spent coffee ground. LWT Food Sci. Technol. 2013; 54(2): 557-563. Publisher Full Text

60. Ateş G, Elmacı Y: Physical, chemical and sensory characteristics of fiber-enriched cakes prepared with coffee silverskin as wheat flour substitution. J. Food Meas. Charact. 2018; 13(1): 755-763. Publisher Full Text

61. Garcia-Serna E, Martinez-Saez N, Mesias M, et al.: Use of Coffee Silverskin and Stevia to Improve the Formulation of Biscuits. Pol. J. Food Nutr. Sci. 2014 2014; 64(4): 243-251.

62. Ateş G, Elmacı Y: Coffee silverskin as fat replacer in cake formulations and its effect on physical, chemical and sensory attributes of cakes. Lwt. 2018; 90: 519-525.

Publisher Full Text

63. Clifford MN, Ramirez-Martinez JR: Phenols and caffeine in wetprocessed coffee beans and coffee pulp. Food Chem. 1991; 40(1): 35-42. Publisher Full Text

64. Pourfarzad A, Mahdavian-Mehr H, Sedaghat $\mathrm{N}$ : Coffee silverskin as a source of dietary fiber in bread-making: Optimization of chemical treatment using response surface methodology. LWT Food Sci. Technol. 2013; 50(2): 599-606. Publisher Full Text

65. Panusa A, Petrucci R, Lavecchia R, et al.: UHPLC-PDA-ESI-TOF/MS metabolic profiling and antioxidant capacity of arabica and robusta coffee silverskin: Antioxidants vs phytotoxins. Food Res. Int. 2017 Sep; 99(Pt 1): 155-65.

PubMed Abstract | Publisher Full Text

66. Silva Faria WC, Oliveira MG, Cardoso da Conceição E, et al.: Antioxidant efficacy and in silico toxicity prediction of free and spray-dried extracts of green Arabica and Robusta coffee fruits and their application in edible oil. Food Hydrocoll. 2020; 108: 106004.

Publisher Full Text

67. Wolska J, Janda K, Jakubczyk K, et al.: Levels of Antioxidant Activity and Fluoride Content in Coffee Infusions of Arabica, Robusta and Green Coffee Beans in According to their Brewing Methods. Biol. Trace Elem. Res. 2017 Oct; 179(2): 327-333. PubMed Abstract | Publisher Full Text | Free Full Text

68. Brewer MS: Natural Antioxidants: Sources, Compounds Mechanisms of Action, and Potential Applications. Compr. Rev. Food Sci. Food Saf. 2011; 10(4): 221-247. Publisher Full Text

69. Hasballah K, Sarong M, Rusly R, et al:: Antiproliferative Activity of Triterpenoid and Steroid Compounds from Ethyl Acetate Extract of Calotropis gigantea Root Bark against P388 Murine Leukemia Cell Lines. Sci. Pharm. 2021; 89(2) Publisher Full Text

70. Jeszka-Skowron M, Zgoła-Grześkowiak A, Grześkowiak T: Phenolic Compounds in Coffee and Tea Beverages. Analytical Methods in the Determination of Bioactive Compounds and Elements in Food. 2021; p. 31-81.

71. Haile M, Kang W: Antioxidant Activity, Total Polyphenol, Flavonoid and Tannin Contents of Fermented Green Coffee Beans with Selected Yeasts. Fermentation. 2019; 5(1). Publisher Full Text

72. Yang K, Zhang L, Liao $P$, et al.: Impact of Gallic Acid on Gut Health: Focus on the Gut Microbiome, Immune Response, and Mechanisms of Action. Front. Immunol. 2020; 11: 580208. PubMed Abstract | Publisher Full Text | Free Full Text

73. Daré RG, Nakamura CV, Ximenes VF, et al.: Tannic acid, a promising anti-photoaging agent: Evidences of its antioxidant and antiwrinkle potentials, and its ability to prevent photodamage and MMP-1 expression in L929 fibroblasts exposed to UVB. Free Radic Biol. Med. 2020 2020/11/20/; 160: 342-355.

PubMed Abstract | Publisher Full Text

74. Guglielmetti A, Fernandez-Gomez B, Zeppa G, et al.: Nutritional Quality, Potential Health Promoting Properties and Sensory Perception of an Improved Gluten-Free Bread Formulation Containing Inulin, Rice Protein and Bioactive Compounds Extracted from Coffee Byproducts. Polish Journal of Food and Nutrition Sciences. 2019; 69(2): 157-166. Publisher Full Text

75. Ontawong A, Duangjai A, Muanprasat C, et al.: Lipid-lowering effects of Coffea arabica pulp aqueous extract in Caco-2 cells and hypercholesterolemic rats. Phytomedicine. 2019 2019/01/01/; 52: 187-197. PubMed Abstract | Publisher Full Text

76. Nurhayati N, Yuwanti S, Urbahillah A: Karakteristik Fisikokimia Dan Sensori Kombucha Cascara (Kulit Kopi Ranum). Jurna Teknologi dan Industri Pangan. 2020; 31(1): 38-49. Publisher Full Text

77. Rebollo-Hernanz M, Zhang Q, Aguilera Y, et al.: Phenolic compounds from coffee by-products modulate adipogenesisrelated inflammation, mitochondrial dysfunction, and insulin resistance in adipocytes, via insulin/PI3K/AKT signaling pathways. Food Chem. Toxicol. 2019 2019/10/01/; 132: 110672. PubMed Abstract| Publisher Full Text 


\section{Open Peer Review}

\section{Current Peer Review Status:}

\section{Version 1}

Reviewer Report 20 May 2022

https://doi.org/10.5256/f1000research.119070.r136770

(C) 2022 Panahi G. This is an open access peer review report distributed under the terms of the Creative Commons Attribution License, which permits unrestricted use, distribution, and reproduction in any medium, provided the original work is properly cited.

\section{Ghodratollah Panahi}

Department of Biochemistry, Faculty of Medicine, Tehran University of Medical Sciences, Tehran, Iran

In this research, the authors systematically reviewed the studies that evaluated the antioxidant activity of coffee by-products obtained from different coffee variants. They provide evidence that, depending on the processing method and variant, coffee by-products have high antioxidant activities. It is suggested that these compounds could be used as additives in foods, beverages, and cosmetics but their benefits in skincare products require further investigation.

The article is well written and methodologically well done. Congratulations to the authors of this research, and I think the article is ready to be accepted and published.

Are the rationale for, and objectives of, the Systematic Review clearly stated? Yes

Are sufficient details of the methods and analysis provided to allow replication by others? Yes

Is the statistical analysis and its interpretation appropriate?

Yes

Are the conclusions drawn adequately supported by the results presented in the review? Yes

Competing Interests: No competing interests were disclosed.

Reviewer Expertise: Diabetes, endocrine disorder, miRNA, molecular Biology

I confirm that I have read this submission and believe that I have an appropriate level of expertise to confirm that it is of an acceptable scientific standard. 
Reviewer Report 11 April 2022

https://doi.org/10.5256/f1000research.119070.r128542

(C) 2022 Salim E. This is an open access peer review report distributed under the terms of the Creative Commons Attribution License, which permits unrestricted use, distribution, and reproduction in any medium, provided the original work is properly cited.

\section{Emil Salim}

Faculty of Pharmacy, Universitas Sumatera Utara, North Sumatera, Indonesia

Coffee depulping processes generate solid waste that threatens the environment. Many researchers reported that coffee by-products have the potential as antioxidant sources. This systematic review aimed to assess the antioxidant activity of coffee by-products derived from various coffee varieties (arabica and robusta) and processing techniques. As of May 29, 2021, this study was carried out for papers published within 2011-2021 using Embase, Medline, BMJ, Web of Science, Science Direct, Cochrane, and PubMed databases.

PRISMA guidelines were used to collect information on the type of specimen, processing procedures, and antioxidant activity. Aqueous extraction was the most common method to obtain the antioxidant from various coffee by-products, followed by methanolic and ethanolic extraction. The antioxidant properties varied depending on coffee by-products (cascara, pulp, husk, silverskin, and parchment) and processing method. Coffee by-products contain antioxidant compounds that could be employed as food, beverage, and cosmetic additives.

This systematic review is critical for identifying, evaluating, and summarising the antioxidant activity of coffee by-products obtained from different coffee varieties (arabica and robusta) and processing procedures. The review's rationale, objective, and method were clearly stated, and the selected reports support the conclusion.

However, to improve the quality of this review, I suggest some corrections:

1. "Results: Our data suggested that aqueous extract was found to be the most common processing method used to obtain the antioxidant from various coffee by-products, followed by methanol and ethanol extract." I suggest that aqueous extract.....methanol and ethanol extract are replaced by aqueous extraction......methanol and ethanol extraction.

2. "Many studies have been conducted in coffee." This sentence is unclear; please add more information about the studies.

3. "Phenolics, flavonoids, and tannins are among the common compounds found in aqueous extracts of coffee husks, coffee pulp, and coffee, silverskin, 22,38 which are identical to coffee bean." It should be 'coffee silverskin' (without a comma).

4. Staphylococcus Epidermidis and Pseudomonas Aeruginosa should be written as Staphylococcus epidermidis and Pseudomonas aeruginosa.

\section{Are the rationale for, and objectives of, the Systematic Review clearly stated?}


Yes

Are sufficient details of the methods and analysis provided to allow replication by others? Yes

Is the statistical analysis and its interpretation appropriate?

Not applicable

Are the conclusions drawn adequately supported by the results presented in the review? Yes

Competing Interests: No competing interests were disclosed.

Reviewer Expertise: Natural product, innate immunity

I confirm that I have read this submission and believe that I have an appropriate level of expertise to confirm that it is of an acceptable scientific standard.

The benefits of publishing with F1000Research:

- Your article is published within days, with no editorial bias

- You can publish traditional articles, null/negative results, case reports, data notes and more

- The peer review process is transparent and collaborative

- Your article is indexed in PubMed after passing peer review

- Dedicated customer support at every stage

For pre-submission enquiries, contact research@f1000.com 